\title{
Serum lysozyme levels in malignant histiocytosis of the intestine
}

\author{
J. R. HODGES, P. ISAACSON, O. E. EADE, AND RALPH WRIGHT \\ From the Departments of Medicine and Pathology, Southampton University Hospitals, Southampton
}

SUMMARY Serum lysozyme levels were significantly raised in a group of eight patients with malabsorption associated with gastrointestinal lymphomas of a type recently characterised as malignant histiocytosis of the intestine. In four of the cases, levels were markedly raised. In contrast there was no significant difference between groups of patients with uncomplicated adult coeliac disease and healthy controls. The estimation of serum lysozyme is a simple test to perform and may be valuable in the diagnosis of malignant histiocytosis of the intestine, in particular differentiating it from uncomplicated adult coeliac disease.

In 1922 Fleming discovered a 'remarkable bacteriolytic element' in tissues and secretions which he called lysozyme (muramidase). It is a basic protein with a low molecular weight and is found in tears, saliva, sputum, intestinal secretions, and intracellularly in high concentrations in granulocytes and histiocytes. Raised serum lysozyme levels have been found in myeloproliferative disorders, particularly of the monocytic variety (Osserman and Lawlor, 1966). Moderate rises in serum lysozyme activity have also been reported in granulomatous diseases such as tuberculosis (Perillie et al., 1973), and sarcoidosis (Pascual et al., 1973). Recently, slightly raised serum levels were reported in inflammatory bowel disease, and it was suggested that this may be of help in discriminating Crohn's disease from other forms (Falchuk et al., 1975). However, the latter finding has not been confirmed by subsequent workers (Dronfield and Langman, 1975; Mallas et al., 1976; Nugent et al., 1976; Peeters et al., 1976).

The recent characterisation of a group of lymphomas associated with malabsorption and villous atrophy as a form of malignant histiocytosis of the intestine (Isaacson and Wright, 1978a, b) and our finding of a markedly raised serum lysozyme level in two patients with the condition, suggested that determination of this enzyme in the serum of unresponsive coeliac patients may help in the detection of those patients who have a lymphoma. Thus, the aim of the current study was to compare serum lysozyme levels in patients with malignant histiocytosis of the small intestine with those in uncomplicated adult coeliac disease.

Received for publication 25 May 1979

\section{Methods}

MEASUREMENT OF SERUM LYSOZYME ACTIVITY

Serum lysozyme activity was determined on coded samples, using a modification of the turbidometric method of Smolelis and Hartsell (1949), which is based on the change in turbidity of cell suspensions of Micrococcus lysodekticus. The enzyme reaction was carried out at ambient room temperature.

Standards of $0 \cdot 625,1 \cdot 25,2 \cdot 5,5$, and $10 \mu \mathrm{g} / \mathrm{ml}$ of lysozymes were prepared from crystalline egg-white lysozyme (Sigma Chemicals, St. Louis). To $1 \mathrm{ml}$ of serum in $4 \mathrm{ml}$ of 0.066 phosphate buffer at $\mathrm{pH} 6.2$ was added $4 \mathrm{ml}$ of a $0 \cdot 1 \mathrm{mg} / \mathrm{ml}$ suspension of $M$. lysodekticus (Sigma Chemicals, St. Louis). The optical density at $540 \mathrm{~nm}$ was recorded, using a Pye Unicam Spectrophotometer at exactly 20 minutes after mixture. Samples were diluted with the phosphate buffer in order to read less than the highest standard if necessary.

PATIENTS AND CONTROLS

Serum samples from patients and controls were stored at $-20^{\circ} \mathrm{C}$ before estimation. Samples from deceased patients, some cases of coeliac disease, and some controls were obtained from a bank of sera stored at $-20^{\circ} \mathrm{C}$ for up to four years.

\section{COELIAC DISEASE PATIENTS}

Eighteen patients with coeliac disease were studied. Thirteen females and five males with an age range of 16 to 74 years. Twelve sera had been stored for periods of one or more years. All patients had confirmed coeliac disease with peroral jejunal biop- 
sies showing characteristic changes that had considerably improved after a period of treatment with a gluten-free diet. In seven, serum samples had been obtained before starting the diet.

\section{LYMPHOMA PATIENTS}

Sera were available from eight patients with malignant histiocytosis of the intestine. Five were female and three were male, with an age range from 51 to 76 years. Three specimens had been stored for three years and the remainder for less than nine months. All patients had lymphomatous involvement of the intestinal wall and total villous atrophy. In two cases there was a long history (seven and nine years respectively) of documented malabsorption, and previous jejunal biopsies had shown villous atrophy. These two patients had been diagnosed as having adult coeliac disease and had improved clinically on a gluten-free diet. At the time of the presentation of their gut lymphoma, all eight cases had biochemical and haematological evidence of malabsorption. Seven of these cases are included in the 18 cases of malignant histiocytosis of the intestine described by Isaacson and Wright (1978a).

\section{CONTROLS}

A control group of 18 healthy volunteers included 12 females and six males with an age range of 17 to 65 years. A further group of 18 random sera from patients on whom autoimmune profiles had been requested and which had been stored for three years, was studied. None had inflammatory or neoplastic disorders likely to affect the serum lysozyme level. In this group there were 11 females and seven males, with an age range of 18 to 77 years.

\section{Results}

The results of the serum lysozyme estimation in the various subject groups are shown in the Figure.

There was no significant difference between the group of patients with uncomplicated adult coeliac disease and the control groups. Levels in the lymphoma group were significantly higher than in both the coeliac group $(\mathrm{P}<0.0001)$ and the controls $(P<0.001)$. Levels were significantly higher in the recently obtained control sera than in the longerterm storage group $(\mathrm{P}<0.01)$.

\section{Discussion}

Our findings of significantly raised serum lysozyme levels in patients with malignant histiocytosis of the intestine, associated with malabsorption and villous atrophy, suggest that the estimation of serum lysozyme may be of value in differentiating these

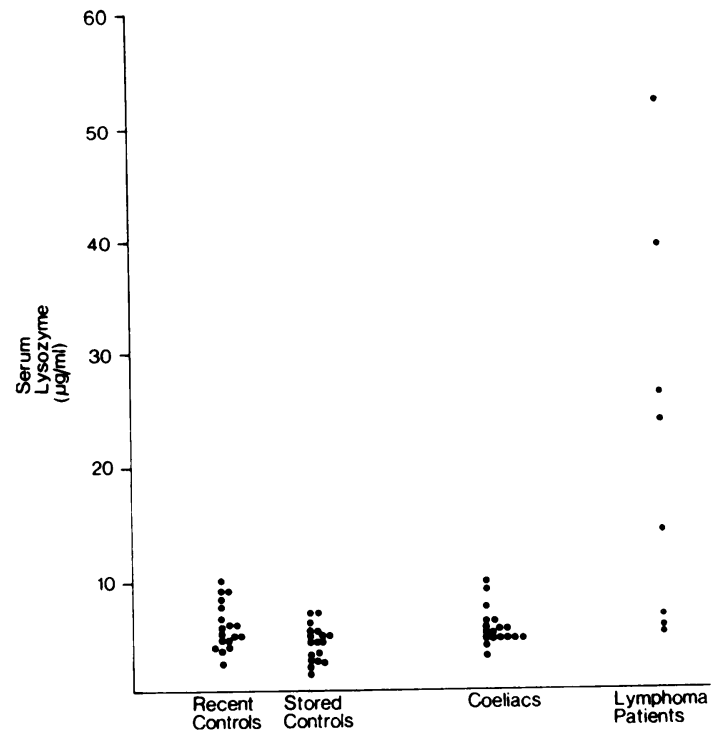

Figure Scattergram showing lysozyme levels in sera from control subjects, coeliac patients and lymphoma patients (controls are separated into those from whom samples were recently obtained and those whose sera had been stored for three years).

patients from those with uncomplicated adult coeliac disease. We found no significant difference in serum lysozyme levels between patients with adult coeliac disease and controls, in contrast with Mallas et al. (1976), who found a significantly raised mean level in a group of coeliac patients. However, in that series there was considerable overlap with the control group.

Markedly raised lysozyme levels were found in four out of five patients with malignant histiocytosis of the intestine whose sera had been stored for less than nine months. Of the three lymphoma patients whose sera had been stored for three years, one was marginally raised and the other two were within the normal range. However, it can be seen that lysozyme levels in the control group of patients whose sera had been stored for three years were significantly lower than in the more recently collected control sera. Thus, there is a degree of deterioration in serum lysozyme activity during long-term storage, and levels in the sera stored for long periods from lymphoma patients may have orignally been much higher. This is supported in part by a recent study (Ward et al., 1978), demonstrating a variable thermolability of serum lysozyme activity in sera from patients with inflammatory bowel disease, but not in healthy controls or patients with various gastrointestinal disorders. They were also able to show by electrophoresis two distinct serum com- 
ponents with lysozymal activity, one of which had more marked thermolability.

There are good theoretical reasons for the finding of raised serum lysozyme levels in our cases. Granulocytes have been shown to contain intracellular concentrations of lysozyme, but release it only during degranulation (Briggs et al., 1966). Histiocytes, on the other hand, have a very high rate of synthesis of the enzyme and release it continuously, independently of phagocytosis or stimulation (Gordon et al., 1974), and are responsible for most of the serum lysozyme activity. Recently developed immunochemical techniques have localised lysozyme in a variety of normal and pathological tissues (Mason and Taylor, 1975). The malignant cells in our cases of malignant histiocytosis of the intestine were strongly positive when stained for lysozyme by the immunoperoxidase technique (Isaacson and Wright, 1978a), so that raised serum lysozyme levels are to be expected in our cases. Other pathological states so far found to be associated with markedly raised lysozyme levels also involve cells of the histiocytic series. These include acute monocytic and myelomonocytic leukaemia (Osserman and Lawlor, 1966). Duffy et al. (1976) have described a case of malignant histiocytosis (histiocytic medullary reticulosis) with a grossly raised serum lysozyme level, although to our knowledge there have been no further studies of levels in this condition.

The association between steatorrhoea and intestinal lymphoma has been recognised for many years: Gough and colleagues (1962) were the first to suggest that long-standing adult coeliac disease may be complicated by the development of a gut lymphoma. Since then, several other workers have supported this finding (Harris et al., 1966; Freeman et al., 1977). These and other authors (Brunt et al., 1969) have described clinical features that suggest the diagnosis of intestinal lymphoma in patients with malabsorption, but these are non-specific and may be misleading. The finding of a high serum lysozyme in a patient with malabsorption strongly suggests the diagnosis of malignant histiocytosis of the intestine, and may help in differentiating these cases from those of uncomplicated adult coeliac disease.

We are grateful to Dr. Morag Chisholm for helpful technical advice and assistance, to the physicians in the Southampton Area for permission to study their patients and to the Cancer Research Campaign.

\section{References}

Briggs, R. S., Perillie, P. E., and Finch, S. C. (1966). Lysozyme in bone marrow and peripheral blood cells. Journal of Histochemistry and Cytochemistry, 14, 167-170.
Brunt, P. W., Sircus, W., and Maclean, N. (1969). Neoplasia and the coeliac syndrome in adults. Lancet, 1, 180-184.

Dronfield, M. W., and Langman, M. J. S. (1975). Serum lysozyme in inflammatory bowel disease. Gut, 16, 985-987.

Duffy, T. P., Knights, E. B., and Eggleston, J. C. (1976). Elevated muramidase levels in histiocytic medullary reticulosis. (Letter). New England Journal of Medicine, 294, 167-168.

Falchuk, K. R., Perrotto, J. L., and Isselbacher, K. J. (1975). Serum lysozyme in Crohn's disease and ulcerative colitis. New England Journal of Medicine, 292, 395-397.

Fleming, A. (1922). On a remarkable bacteriolytic element found in tissues and secretions. Proceedings of the Royal Society, B3 306-317.

Freeman, H. J., Weinstein, W. M., Shnitka, T. R., Piercey, J. R. A., and Wensel, R. H. (1977). Primary abdominal lymphoma. Presenting manifestation of celiac sprue or complicating dermatitis herpetiformis. American Journal of Medicine, 63, 585-594.

Gordon, S., Todd, J., and Cohn, Z. A. (1974). In vitro synthesis and secretion of lysozyme by mononuclear phagocytes. Journal of Experimental Medicine, 139, 1228-1248.

Gough, K. R., Read, A. E., and Naish, J. M. (1962). Intestinal reticulosis as a complication of idiopathic steatorrhoea. Gut, 3, 232-239.

Harris, O. D., Cooke, W. T., Thompson, H., and Waterhouse, J. A. H. (1966). Malignancy in adult coeliac disease and idiopathic steatorrhoea. American Journal of Medicine, 42, 899-912.

Isaacson, P., and Wright, D. H. (1978a). Intestinal lymphoma associated with malabsorption. Lancet, 1, 67-70.

Isaacson, P., and Wright, D. H. (1978b). Malignant histiocytosis of the intestine. Human Pathology, 9, 661-677.

Mallas, E. Terry, J. M., Asquith, P., and Cooke, W. T. (1976). Serum lysozyme in inflammatory bowel and coeliac disease. Journal of Clinical Pathology, 2, 598-600

Mason, D. Y., and Taylor, C. R. (1975). The distribution of muramidase (lysozyme) in human tissues. Journal of Clinical Pathology, 28, 124-132.

Nugent, F. W., Mallari, R., George, H., and Ridley, N. (1976). Serum lysozyme in inflammatory bowel disease. Gastroenterology, 70, 1014-1016.

Osserman, E. F., Lawlor, D. P. (1966). Serum and urinary lysozyme (muramidase) in monocytic and monomyelocytic leukaemia. Journal of Experimental Medicine, 124, 921-951.

Pascual, R. S., Gee, J. B. L., and Finch, S. C. (1973). Usefulness of serum lysozyme measurement in diagnosis and evaluation of sarcoidosis. New England Journal of Medicine, 289, 1074-1076.

Peeters, T. L., Vantrappen, G., and Geboes, K. (1976). Serum lysozyme levels in Crohn's disease and ulcerative colitis. Gut, 17, 300-305.

Perillie, P. E., Kahn, K., and Finch, S. C. (1973). Serum lysozyme in pulmonary tuberculosis. American Journal of Medical Sciences, 265, 297-302. 
Smolelis, A. N., and Hartsell, S. E. (1949). The deter- Ward, M., Mitchell, W. D., and Eastwood, M. (1978). mination of lysozyme. Journal of Bacteriology, 58, 731736. Complex nature of lysozyme activity; evidence of thermolability in inflammatory bowel disease. Journal of Clinical Pathology, 31, 39-43. 